\title{
ВИКОРИСТАННЯ ТЕОРІЇ МАСОВОГО ОБСЛУГОВУВАННЯ ДЛЯ УПРАВЛІННЯ ЛОГІСТИЧНИМ ЗАБЕЗПЕЧЕННЯМ ПРОЄКТІВ
}

\section{APPLICATION THE QUEUING THEORY TO MANAGE THE LOGISTICS SUPPORT OF PROJECTS}

\author{
Гайванович Наталія Василівна \\ кандидат економічних наук, доцент, \\ Національний університет «Львівська політехніка» \\ ORCID: https://orcid.org/0000-0002-8100-290X
}

\author{
Hayvanovych Nataliya \\ Lviv Polytechnic National University
}

\begin{abstract}
Стаття присвячена дослідженню інструментів оптимізаційних рішень, таких як теорія масового обслуговування та обгрунтуванню доцільності їх використання для вдосконалення логістичних процесів як під час реалізації проєктів, так і у функціонуванні ланцюгів поставок загалом. Проведено аналіз транспортно-логістичної системи підприємства (логістичного оператора) з використанням елементів теорії масового обслуговування та здійснено ії оптимізацію за критерієм витрат (витрати очікування на обслуговування і витрати обслуговування). Експериментальне вирішення моделі дало оптимальне значення інтенсивності обслуговування для підприємства, що, в свою чергу, може сприяти досягненню мінімальних сукупних витрат та покращенню ситуації в системі обслуговування досліджуваного підприємства.

Ключові слова: логістичні процеси, логістична система, ланцюг поставок, теорія масового обслуговування, управління проєктами.
\end{abstract}

Статья посвящена исследованию инструментов оптимизационных решений, таких как теория массового обслуживания и обоснованию целесообразности их использования для усовершенствования логистических процессов как при реализации проектов, так и в функционировании цепей поставок в целом. Проведен анализ транспортно-логистической системы предприятия (логистического оператора) с использованием элементов теории массового обслуживания и осуществлено ее оптимизацию по критерию затрат (расходы ожидания на обслуживание и расходы обслуживания). Экспериментальное решение модели дало оптимальное значение интенсивности обслуживания для предприятия, что, в свою очередь, может способствовать достижению минимальных совокупных расходов и улучшению ситуации в системе обслуживания исследуемого предприятия.

Ключевые слова: логистические процессы, логистическая система, цепь поставок, теория массового обслуживания, управление проектами.

The supply chain can be defined as a network of related and interdependent organizations that work mutually and in cooperation to control, manage and improve the flow of materials and information from suppliers to end consumers, and each company is at the center of a network of suppliers and customers. It is the enterprises of the current generation, such as global supply chains, virtual enterprises and e-commerce, that are the drivers of research in the field of process modeling and optimization, incl. and logistics processes. Therefore, it is timely and relevant to study the actual possibilities of using mathematical optimization methods, in particular the theory of queuing, as a tool for optimizing the management of supplies, transportation, storage, etc. in the process of managing the logistic support of projects and for solving problems in supply chains in general. The purpose of the article is to study the tools of optimization solutions, such as the theory of queuing, for improving logistics processes both in the implementation of projects and in the functioning of supply chains in general. The essence and tasks of logistics in project management are investigated in the article. The object of the study for testing a mathematical model based 
on the queuing theory was a company - logistics operator. The analysis of the transport and logistics system of the enterprise (logistics operator) is carried out using elements of the queuing theory and its optimization is carried out according to the cost criterion (waiting costs for service and service costs). The experimental solution of the model gave the optimal value of the intensity of service for the enterprise, which, in turn, can help to achieve the minimum total costs and improve the situation in the service system of the studied enterprise. The obtained results of the optimization model can be used as part of decision-making in the management of logistics processes, and also serve as a fairly weighty justification for investment decisions and investment costs.

Keywords: logistics processes, logistics system, supply chain, queuing theory, project management.

Постановка проблеми. Логістика є важливою складовою діяльності підприємства, що створює умови для зниження витрат і підвищення ефрективності, а логістичний підхід дозволяє ефрективно управляти сукупністю потоків, які генеруються в процесі діяльності компанії, моделювати конорігурацію логістичної системи за основними та супутніми потоками тощо. Відтак у теорії та практиці управління проектами все більш затребуваною стає логістична концепція з її інструментарієм організаційно-економічної оптимізації та раціоналізації. Потенційні можливості використання логістики в управлінні проектами обумовлюються наявністю безлічі потокових процесів, які потребують управління. Це, в свою чергу, пов'язано з тим, що реалізація проектів підтримується різними видами забезпечення, включаючи забезпечення матеріально-технічне (закупівля і доставка матеріалів, сировини, придбання машин і обладнання і т.д.); фрінансове (пошук джерел і залучення інвестицій); кадрове (підбір та управління «командою»); інсормаційне (накопичення, систематизація та оновлення інформації по етапах робіт і видах забезпечення проекту). По суті, логістичний підхід до управління проектами повністю відповідає системному підходу до управління проектами у сорері забезпечення. Найважливішими завданнями логістики в управлінні проектами є, зокрема, такі: створення інтегрованої системи управління матеріальними потоками на основі інфрормаційних потоків; розробка методів управління рухом ресурсів і контролю матеріальних потоків; визначення стратегії і технології фрізичного розподілу ресурсів по роботах проєкту; прогнозування обсягів поставок, перевезень і складування; оптимізація технічної та технологічної структури транспортно-складських комплексів та ін. [18]. А необхідність виконання таких завдань власне для оптимізації логістичних процесів актуалізує потребу у застосуванні математичних методів і моделей, які можуть використовуватися як частина прийняття рішень та управління логістичними процесами.
Аналіз останніх досліджень і публікацій. Особливості логістики, логістичного управління та управління проєктами тривалий час складають істотний предмет наукових досліджень вчених 3-за кордону та з України. Дослідженню питань логістичного управління присвячені праці Бауерсокса Д., Григорак М.Ю., Крістофрера М., Крикавського Є.В., Окландера М.А., Похильченко О.А., Фертча М., Цимбалістової О.А., Чухрай Н.І. та ін. [1; $2 ; 6 ; 7 ; 13 ; 19 ; 20]$. Вагомий внесок у розвиток теорії і практики проектного менеджменту зробили, зокрема, такі вчені, як Керзнер X., Мередіт Дж., Мантел С., Ноздріна Л.В., Петрович Й.М., Новаківський І.І., Тарасенко Л.М. [25; $11 ; 12 ; 14 ; 17]$. Питання логістичного забезпечення бізнес-проектів підприємств досліджувалися Лісуном Я.В [9]. Так, у [9] автор обгрунтовує, що логістичне забезпечення дозволяє покращити управління основними складовими проєкту з використанням відповідних інструментів: 1) управління змістом 3 використанням: дерева цілей, структури робіт відповідно до задуму проєкту, етапів життєвого циклу проекту; 2) управління тривалістю з використанням: сіткових моделей та календарного планування; 3) управління вартістю шляхом фрормування бюджетів; 4) управління якістю на основі структуризації потреб замовників проекту, проектування бізнес-процесів; 5) управління людськими ресурсами як внутрішніми (організаційна структура управління, штатний розклад, матриця відповідальності) так і зовнішніми шляхом оптимізації потоку клієнтів; 6) управління матеріальними ресурсами за результатами структурування ресурсів, їх наявності та графріку постачань; 7) управління інорормаційними ресурсами шляхом формування дерева документів та інформаційної структури; 8) управління ризиками на основі фрормування дерева ризиків та дерева рішень.

Математичні методи оптимізації, як правило, досить часто використовують як інструмент, що дозволяє скоротити час та зменшити витрати на виконання певних процесів [5; 25]. Застосування відповідних методів оптимізації також пропонується і для зниження витрат на 
здійснення логістичної діяльності підприємства, а згодом і ланцюга поставок в цілому. Так, оптимізація процесів складування з використанням математичних симуляційних методів розглядається у [22; 23]. В [28] автори пропонують використовувати для оптимізації процесів складування моделі на основі теорії масового обслуговування. Вибір відповідного методу та його подальше застосування до певного логістичного процесу в логістичній системі чи в ланцюгу поставок може скоротити час виконання процесів, тим самим зменшивши витрати, в т.ч. і на реалізацію проєктів.

Виділення невирішених раніше частин загальної проблеми. Кожна компанія знаходиться в центрі мережі постачальників та клієнтів. Саме підприємства нинішнього покоління, такі як глобальні ланцюги поставок, віртуальні підприємства та е-commerce, є драйверами досліджень у сфері моделювання та оптимізації процесів, в т.ч. і логістичних. Тому своєчасним та актуальним $€$ дослідження власне можливостей використання математичних методів оптимізації, зокрема теорії масового обслуговування, як інструменту для оптимізації управління постачанням, транспортуванням, зберіганням тощо в процесі управління логістичним забезпеченням проектів та для вирішення проблем у ланцюгах поставок загалом.

Формулювання цілей статті (постановка завдання). Метою статті $€$ дослідження інструментів оптимізаційних рішень, таких як теорія масового обслуговування для вдосконалення логістичних процесів як під час реалізації проєктів, так і у фрункціонуванні ланцюгів поставок загалом.

Виклад основного матеріалу дослідження. Із сутності логістичного підходу до еластичного реагування на очікування клієнта, що динамічно змінюються, витікає потреба в координації процесів, а головним чином синхронізації їх перебігу в часі і просторі. Нові зразки управління підприємством акцентують роль чинника часу. Стратегії, що закладають так звану компресію часу, ведуть до виключення відрізків часу, в яких не створюється додана вартість, а виникають додаткові витрати. «...компресія часу представляє наймолодшу за віком стратегію конкуренції; визначається як стратегія, що забезпечує досягнення якнайбільшого по найнижчих витратах, в найкоротший час» [24, с. 119]. Чинник часу набирає нового значення в оцінці ефективності процесів, що відбуваються на підприємстві. Слід його розглядати у двох площинах: у виробничій площині і ширше - в ланцюзі поставок, який охоплює дуже широку сореру різнорідних процедур і дій, починаючи від логістики постачання [27, с. 108]. Тут знаходяться основні процедури, такі як: закупівля, транспортування, складування. Вони $€$ наслідком фрізичного переміщення матеріальних потоків. Особливе місце в логістичному ланцюзі займає транспортна проблематика.

Одним 3 аспектів оцінки ефективності транспорту $є$ невигідний (на тлі західних підприємств) рівень продуктивності транспорту. Це $є$ результатом, зокрема, видовженого, необгрунтованого очікування на обслуговування розвантаження на перевантажувальній площі чи завантаження при складських рампах. Довгий час очікування в черзі означає нижчий рівень використання транспортних засобів, а як наслідок - зростаючі витрати. Як подано у [30] «...досягнення мети або прибутку у випадку закупівель означає, головним чином, зменшення витрат коштів, яке досягається через зниження витрат транспорту».

Однією зі сорер прийняття рішень стратегічного характеру, пов'язаних з транспортом у постачанні, $€$ організація структури бази поставок. Рішення, які приймаються в цій сорері, стосуються кількості постачальників і організації поставок. В свою чергу, кількість постачальників залежить від вибору між постачанням 3 багатьох джерел або з одного. Наслідком прийнятої структури бази поставок $€$ сорера дій адміністративного характеру, пов'язаних з введенням документів про закупівлі до інорормаційної системи, а надалі розвантаження товару, тобто експедиція. Завданням експедиції $\epsilon$ якомога швидке вивантаження товару 3 транспортних засобів до місць складування, так, щоб зберегти справність переміщення матеріалів. Місце вивантаження може бути «вузьким місцем» в потоці переміщення товарів. Оптимізація логістичних процесів, пов'язаних із постачанням, в тому числі також оптимізація «технології» завантаження і вивантаження, вимагає застосування процедури математичного моделювання, а отримані результати можуть бути основою для прийняття рішень керівниками фрірми.

Говорячи про транспортну систему, слід врахувати глибші залежності, а не тільки прості зв'язки між елементами системи. Логістичні взаємозв'язки в ссрері транспорту виникають 3 прийнятої структури бази поставок і характеризуються значною кількістю критеріїв. Відтак, 3 точки зору прийняття рішення, маємо справу 3 проблемою багатокритеріальної оптимізації. Для потреб даної розробки в якості критерію оптимі- 
зації прийнята мінімізація витрат системи, а точніше - загальних витрат очікування транспортних одиниць на обслуговування (вивантаження), а також витрат обслуговування.

Загалом найбільш часто застосовуваними методами математичної оптимізації, які використовуються як інструмент оптимізації при управлінні логістичними процесами, є: моделі управління запасами; теорія масового обслуговування (або теорія черг, queuing theory); методи теорії графрів тощо.

Моделі масового обслуговування обчислюють оптимальну кількість пунктів обслуговування клієнтів/замовлень (серверів), щоб мінімізувати витрати на бізнес. Враховується середній коефіцієнт прибуття замовлень, середній рівень обслуговування споживачів, витрати на час очікування замовлення (незадоволеність клієнтів) та витрати на роботу пунктів обслуговування споживачів. Моделі теорії черг використовуються для отримання apriori iнdpopмації не лише про важливі показники ефективності, такі як довжина черги, час відповіді та час очікування, але й інші показники есрективності, такі як: (а) ймовірність виникнення будь-якої затримки, (б) ймовірність загальної затримки понад заздалегідь визначене значення, (в) ймовірність того, що всі об'єкти обслуговування будуть простоювати, (г) очікуваний час простою всього об'єкта та (д) вірогідність того, що клієнт покине з чергу через недостатність місця для очікування. Деякі види завдань організації черг включають визначення відповідної кількості об'єктів обслуговування для задоволення очікуваного попиту, а також визначення ефективності і кількості точок/серверів різних типів на об'єктах обслуговування [21].

Характерні елементи такої системи масового обслуговування - це:

1) постійно поступаючі заявки/замовлення тощо; 2) черга об'єктів, що очікують на обслуговування; 3) місця обслуговування (наприклад, місця діагностики транспортного засобу, місце вивантаження тощо). Схематично структуру системи масового обслуговування представлено на рис. 1.

Проявом оптимального керування чергами $\epsilon$ не тільки скорочення часу очікування на обслуговування, що приносить задоволення клієнта, але і зростання ефективності управління фрірмою, а тим самим зростання доходності і рентабельності фрірми. Мова йде про вирішення проблеми: чи утримувати існуючу кількість місць обслуговування, чи її збільшити або скоротити.

3 використанням теорії масового обслуго- вування можуть бути вирішені численні задачі. Так, в організації торгівлі ці методи дають можливість визначити оптимальну кількість торговельних точок певного профілю, чисельність продавців, частоту завезення товарів, інші параметри. Іншим характерним прикладом систем масового обслуговування можуть слугувати склади або бази постачальницькозбутових організацій. Задача теорії масового обслуговування зводиться до того, щоб установити оптимальне співвідношення між кількістю вимог, що надійшли на базу на обслуговування, і числом обслуговуючих пристроїв, за якого сумарні витрати на обслуговування і збитки від простою транспорту або втрати клієнтів були б мінімальними. Теорія масового обслуговування може знайти застосування і при розрахунку площі складських приміщень, при цьому складська площа розглядається як обслуговуючий пристрій, а прибуття транспортних засобів на розвантаження - як вимога [28].

Розділом теорії масового обслуговування $€$ теорія черг, яка вивчає системи, у яких вимоги, що застають систему зайнятою, не губляться, а очікують її звільнення й потім обслуговуються в тому або іншому порядку (часто 3 наданням пріоритету певним категоріям вимог). У системах масового обслуговування, в яких заявки на елементарні операції надходять у випадкові моменти часу або обслуговуються протягом випадкових проміжків часу, поява черг - неминуче «зло». За великої кількості каналів обслуговування (ремонтних бригад, продавців, транспортних одиниць і т. п.) система зазнає збитків через можливі тривалі простої каналів. За малої кількості каналів обслуговування, збитки системи спричиняють черги, які накопичуються [8; 15, с. 78-79].

У даній статті для розрахунку оптимізаційної моделі використано елементи теорії масового обслуговування, тому що логістичну транспортну систему - часто з'єднану зі складом - можна трактувати як виокремлену 3 оточення множину засобів, метою яких $€$ трансформація вхідних потоків (потоків товарної маси) у вихідні потоки (реалізація вантажів). У такому представленні - як логістичну систему - можна визнати склад, перевантажувальний термінал або логістичний центр. У даному випадку маємо справу з постійно поступаючими протягом певного періоду часу заявами, з чергою об'єктів, що очікують на обслуговування, а також $з$ місцями обслуговування, тобто місцями вивантаження. 3 сутності фрормування черги слідує, що якщо заяви напливають в моменти часу, які неможливо 


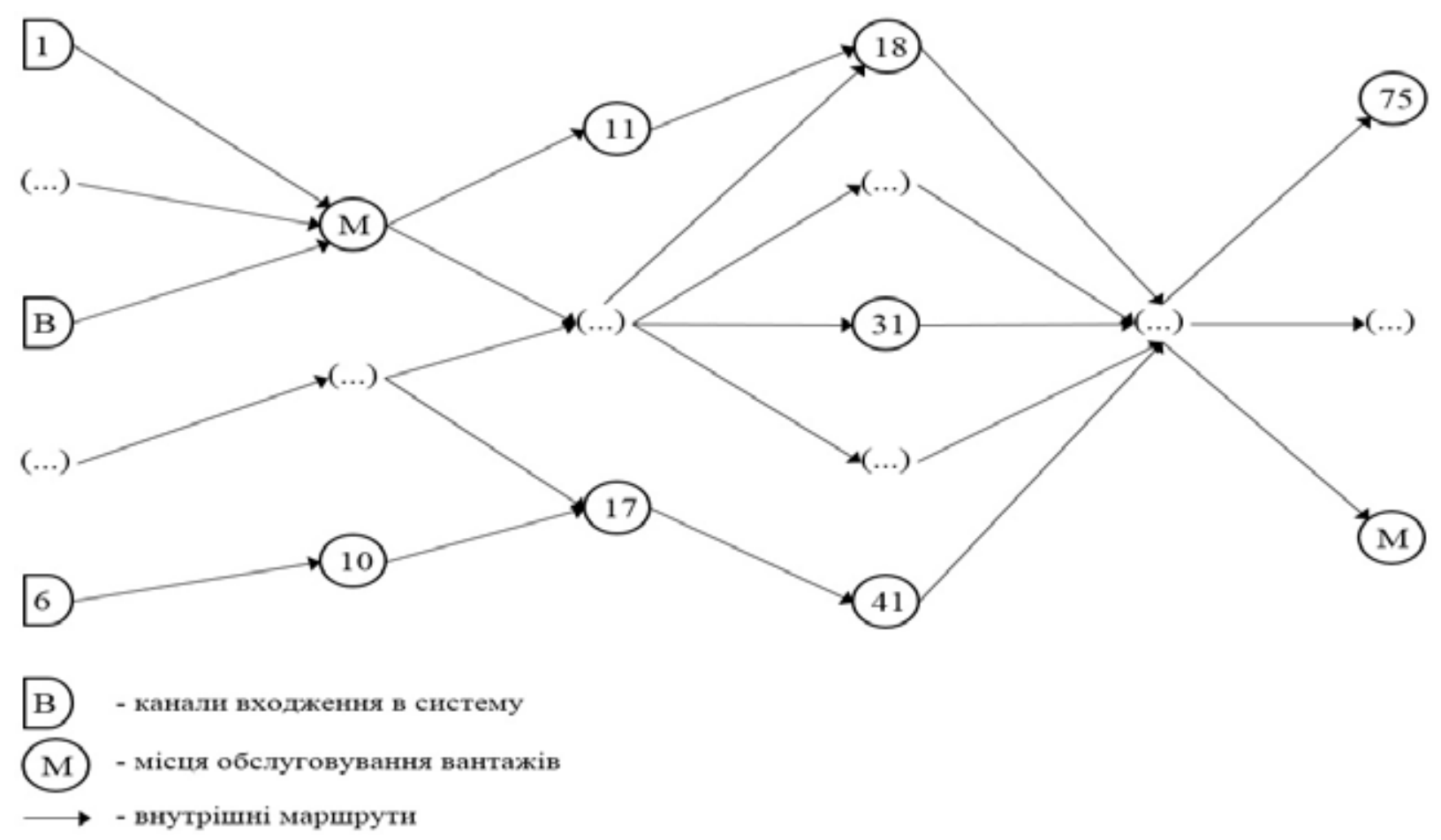

Рис. 1. Структура логістичної системи як мережі масового обслуговування

Джерело: розроблено автором на основі [30]

встановити попередньо, то можна їх визнати випадковими змінними (випадковими подіями), такими, що можна описати відповідними розкладами ймовірності [29]. Характерна при настанні цих випадків випадковість дозволяє використати в аналітичному процесі розподіл Пуассона, а також пов'язаний з ним розподіл $\left(P_{x}(t)=\frac{(\mu t)^{x}}{X !} \cdot e^{-\mu t}-\right.$ імовірність того, що за час $t$ відбудеться $X$ подій). Характеристикою потоку вимог $€ \lambda$ - інтенсивність надходження замовлень в систему, тобто середня кількість замовлень, що надходять в систему за одиницю часу. Механізм обслуговування визначається тривалістю процедур обслуговування $(\mathrm{t})$ та інтенсивністю обслуговування $(\mu)$, тобто кількістю вимог, які обслуговуються за одиницю часу. Існує обернена залежність між часом та інтенсивністю обслуговування, яка виражається срормулою $t=\frac{1}{\mu}$.

Поставлена проблема стосується визначення оптимальних рішень окремих елементів системи або кількості місць обслуговування, «густини» обслуговування, часу обслуговування. Основні параметри і фрормули моделі для оцінювання результатів оптимізації транспортно-логістичної системи досліджуваного логістичного оператора 3 використанням теорії масового обслугову- вання, а також їх оцінка представлені в таблиці 2.

Основні параметри, що характеризують транспортно-логістичну систему досліджуваного логістичного оператора, представлені в таблиці 1.

Розвиваючи інтерпретацію результатів (табл. 2) під кутом есрективності системи обслуговування, встановимо ймовірність того, що клієнт очікуватиме на обслуговування більше ніж 1,37 год., наприклад, 1,5 год. Відповідь буде наступною:

$$
\left.P(t\rangle t_{0}\right)=\rho e^{-t_{0}(\mu-\lambda)},
$$

тобто $P(t>1,5)=054 e^{-1,5(0,79-0,43)}=0,29$.

Отриманий результат свідчить, що триваліше очікування на обслуговування $€$ мало ймовірним (ймовірність становить тільки 29\%).

Можна запропонувати оптимізаційну модель на основі використання теорії масового обслуговування щодо транспортно-логістичної системи, основу якої становить критерій:

$K(\mu)=K_{p o}+K_{o b}$, через прийнятий критерій має форму:

$$
\min K(\mu)=\min \left[\mu K o b j+\frac{\lambda}{\mu-\lambda} \cdot K_{p o j}\right]
$$

У цій моделі змінною прийняття рішення $\epsilon \mu$, a:

$K_{\text {obj }}$ - питомі витрати обслуговування;

$K_{p о j}-$ питомі витрати очікування на початок обслуговування; 
Таблиця 1

Фактичні параметри, що характеризують транспортно-логістичну систему

\begin{tabular}{|c|c|c|c|c|}
\hline $\begin{array}{c}\text { Квартали } \\
\text { (досліджуваний } \\
\text { період } 2 \text { роки) }\end{array}$ & $\begin{array}{c}\text { Середній } \\
\text { (квартальний) } \\
\text { час } \\
\text { знаходження } \\
\text { замовлення в } \\
\text { системі }\end{array}$ & \begin{tabular}{|} 
Інтенсивність \\
руху ( $\rho)$, тобто \\
відношення \\
кількості \\
автомобілів, \\
які прибувають, \\
до кількості \\
обслужених \\
автомобілів \\
(при значенні >1 \\
створюється \\
черга) \\
\end{tabular} & $\begin{array}{c}\text { Витрати (в грн) } \\
\text { обслуговування- } \\
\text { розвантаження, } \\
\left(K_{o b j}\right)\end{array}$ & $\begin{array}{c}\text { Витрати часу } \\
\text { очікування } \\
\text { автомобільного } \\
\text { складу } \\
\text { на початок } \\
\text { обслуговування, } \\
\left(K_{p o j}\right)\end{array}$ \\
\hline $\begin{array}{l}\text { 1-ий рік } \\
\text { I кB. } \\
\text { II кв. } \\
\text { III кB. } \\
\text { IV кB. }\end{array}$ & $\begin{array}{l}2,5 \\
2,0 \\
1,5 \\
2,5\end{array}$ & $\begin{array}{l}0,8 \\
1,1 \\
1,0 \\
1,1\end{array}$ & $\begin{array}{l}890 \\
800 \\
750 \\
880\end{array}$ & $\begin{array}{l}250 \\
220 \\
200 \\
300 \\
\end{array}$ \\
\hline $\begin{array}{l}\text { 2-ий рік } \\
\text { I кB. } \\
\text { II кв. } \\
\text { III кB. } \\
\text { IV кB. } \\
\end{array}$ & $\begin{array}{l}2,8 \\
3,0 \\
1,5 \\
2,5 \\
\end{array}$ & $\begin{array}{l}1,0 \\
1,0 \\
0,9 \\
0,8 \\
\end{array}$ & $\begin{array}{l}920 \\
830 \\
730 \\
980 \\
\end{array}$ & $\begin{array}{c}323,75 \\
- \\
- \\
- \\
\end{array}$ \\
\hline $\begin{array}{c}\text { Середні } \\
\text { значення за два } \\
\text { роки }\end{array}$ & $\begin{array}{c}2,28 \\
\text { (тобто } \lambda=0,43 \text { ) }\end{array}$ & $\begin{array}{c}0,97(=\rho), \\
\text { тоді } \mu=0,44 \\
\text { (оскільки } \mu=\frac{0,43}{0,97} \text { ) }\end{array}$ & 847,5 & 258,75 \\
\hline
\end{tabular}

Джерело: складено на основі внутрішньої інфрормації логістичного оператора та власних розрахунків

$\frac{\lambda}{\mu-\lambda}-$ середня кількість автомашин, які перебувають в системі і очікують в черзі на обслуговування.

Для знаходження мінімального значення $\mu$ знайдемо першу похідну фрункції в (1):

$\frac{d K(\mu)}{d \mu}=\left(\mu \cdot K_{o b j}+\frac{\lambda}{\mu-\lambda} \cdot K_{p o j}\right)^{\prime}=K_{o b j}-\frac{\lambda}{(\mu-\lambda)^{2}} \cdot K_{p o j}$

Прирівняємо першу похідну до нуля і отримаємо:

$$
K_{o b j}=\frac{\lambda}{(\mu-\lambda)^{2}} \cdot K_{p o j} ;(\mu-\lambda)^{2}=\frac{\lambda}{K_{o b j}} \cdot K_{p o j} .
$$

Звідси

$$
\mu=\lambda+\sqrt{\frac{\lambda \cdot K_{\text {poj }}}{K_{\mathrm{obj}}}}
$$

Шукаємо другу похідну

$$
K^{\prime \prime}\left(\mu^{*}\right)=\frac{2 \lambda}{\left(\sqrt{\lambda \frac{K_{p o j}}{K_{o b j}}}\right)^{3}} K_{p o j}>0
$$

Якщо в точці $\mu^{*}$ ії значення більше нуля, то в цій точці фрункція К $\left(\mu^{\star}\right)$ досягає мінімуму.

Розв'язок (3) - оптимальне значення інтенсивності потоку обслуговування.

Експериментальне вирішення моделі дало оптимальне значення інтенсивності обслу- говування (для досліджуваного логістичного оператора):

$$
\mu^{*}=0,43+\sqrt{0,43 \frac{258,75}{847,5}}=0,79,
$$

Підставивши $\mu^{*}$ в (1), можемо провести мінімізацію сукупних витрат часу $K\left(\mu^{*}\right)$ :

$$
K\left(\mu^{*}\right)=979,0
$$

Визначене значення інтенсивності обслуговування $\mu^{*}=0,79$ при густині руху на рівні $\rho \leq 1$ в значній мірі покращує ситуацію в системі обслуговування підприємства. Приймаючи, що норма прибуттів залишається на незмінному рівні, система досягає значної стабільності, а ймовірність довгих черг зменшується.

Проведемо мінімізацію сукупних витрат $(K(\mu))$, які $€$ сумою витрат очікування на розвантаження (простій) $K_{p o}$ і витрат обслуговування клієнта $K_{\text {ob }}$.

Необхідною умовою існування мінімуму фрункції $K(\mu) \in K^{\prime}(\mu)=0$, що рівнозначне $K_{\text {obj }}-\frac{\lambda}{(\mu-\lambda)^{2}} K_{p o j}=0$, а звідси, $\mu^{*}=\lambda+\sqrt{\lambda \frac{K_{p o j}}{K_{o b j}}}$, для $\left.\lambda \geq 0 ; K_{p o j} \geq 0, K_{o b j}\right\rangle 0$.

Достатньою умовою існування мінімуму фрункції $K(\mu) \in K^{\prime \prime}\left(\mu^{*}\right)>0$. 
Таблиця 2

Основні параметри для оцінювання результатів оптимізації транспортно-логістичної системи з використанням теорії масового обслуговування

\begin{tabular}{|c|c|c|}
\hline $\begin{array}{l}\text { Параметрl } \\
\text { аналітична } \\
\text { формула }\end{array}$ & $\begin{array}{c}\text { Розрахункова } \\
\text { величина }\end{array}$ & Розрахункова оцінка \\
\hline$\lambda$ & 0,43 & $\begin{array}{l}\text { Інтенсивність надходження замовлень в систему, } \\
\text { тобто середня кількість замовлень, що надходять } \\
\text { в систему за одиницю часу. }\end{array}$ \\
\hline$\mu / \mu=1 / \mathrm{t}$ & $0,79 *(0,44)$ & $\begin{array}{l}\text { Інтенсивність обслуговування } \mu \text {, тобто число вимог } \\
\text { клієнтів, які обслуговуються за одиницю часу. } \\
\text { Оптимальне значення }\left(^{*}\right) \text { розраховується на основі } \\
\text { критерію мінімізації витрат }(K[\mu])\end{array}$ \\
\hline$\rho\left(\frac{\lambda}{\mu}\right)$ & $0,54\left(\frac{0,43}{0,79}\right)$ & Ступінь використання каналу обслуговування \\
\hline$Q_{\left(\mu^{*}\right)}^{*}=\frac{\rho^{2}}{1-\rho}$ & 0,63 & $\begin{array}{l}\text { Середня оптимальна довжина черги (значення 0,63 - } \\
\text { в принципі черга на обслуговування відсутня) }\end{array}$ \\
\hline$P\left(n-n_{0}\right)=q^{n_{0}+1}$ & 0,37 & Ймовірність того, що буде більше автомашин в системі, ніж $n_{0}$ \\
\hline$E(\tau)=\frac{1}{\lambda} \cdot \frac{\rho^{2}}{1-\rho}$ & 1,37 & $\begin{array}{l}\text { Оптимальний час очікування на обслуговування } \\
\text { (розвантаження) клієнта }\end{array}$ \\
\hline
\end{tabular}

Джерело: власна розробка на основі внутрішньої інфрормації логістичного оператора

Оскільки ми маємо:

$$
K^{\prime \prime}\left(\mu^{*}\right)=\frac{2 \lambda}{(\mu-\lambda)^{3}} K_{p o j} \text { i } K^{\prime \prime}\left(\mu^{*}\right)=\frac{2 \lambda}{\left(\sqrt{\lambda \frac{K_{p o j}}{K_{o b j}}}\right)^{3}} K_{p o j}>0
$$

Функція $K(\mu)$ приймає мінімум при значенні $\mu^{*}=\lambda+\sqrt{\lambda \frac{K_{p o j}}{K_{o b j}}}$ при значеннях $\lambda=0,43$; $K_{\text {роj }}=258,75 ; K_{\text {оbj }}=847,5$ (див. табл. 1). Оптимальне значення $\mu^{*}=0,79$.

Оскільки ланцюг поставок можна визначити як мережу пов'язаних та взаємозалежних організацій, які взаємо та в кооперації працюють над контролем, управлінням та покращенням потоку матеріалів та інсрормації від постачальників до кінцевих споживачів, а кожна компанія знаходиться в центрі мережі постачальників та клієнтів, то доцільним буде використання принципів і моделей теорії масового обслуговування для дослідження та вирішення проблем у ланцюгах поставок.

Висновки. Проведений аналіз транспортно-логістичної системи підприємства (логістичного оператора) і їі оптимізація за критерієм витрат (витрати очікування на обслуговування і витрати обслуговування) дозволяє зробити наступні висновки:

- визначене оптимальне значення інтенсивності обслуговування $\mu^{*}$ свідчить про високу стабільність системи обслуговування, що підтверджує значення $\rho<1(\rho=0,54)$ у даній системі;

- необхідним є збільшення кількості місць обслуговування майже у два рази, оскільки

$$
\frac{\mu}{\lambda}=\left(\frac{0,79}{0,44} \cdot 100\right)=179,5 \%
$$

- пропоноване рішення, яке оптимізує ефрективність системи обслуговування, пов'язане 3 інвестиційними рішеннями, головним чином 3 додатковими інвестиційними витратами.

Використання принципів і моделей теорії масового обслуговування буде доцільним не лише для оптимізації логістичних та інших процесів в межах окремої організації/логістичної системи, але і для вирішення проблем і налагодження кращого фрункціонування ланцюгів поставок.

\section{СПИСОК ВИКОРИСТАНИХ ДЖЕРЕЛ:}

1. Бауэрсокс Д., Клосс Д. Логистика: интегрированная цепь поставок. 2-е изд. Москва : ЗАО «Олимп-Бизнес», 2006. $640 \mathrm{C}$.

2. Григорак М.Ю. Аналіз бізнес-моделей та стратегій інноваційного розвитку постачальників логістичних послуг. Технологический аудит и резервы производства. 2016. № 2(5). С. 29-38. doi: 10.15587/2312-8372.2016.65948 
3. Голдратт Э.М., Кокс Д. Цель. Процесс непрерывного совершенствования. Минск : Попурри, 2004. 556 с.

4. Детмер У. Теория ограничений Голдратта. Системный подход к непрерывному совершенствованию. Москва : «Альпина Паблишер», 2010. 448 с.

5. Дьоміна В.М. Оптимізаційні методи та моделі. Моделювання систем масового обслуговування : конспект лекцій. Харків : ХНАУ, 2015. 42 с.

6. Крикавський $€$., Похильченко О., Фертч М. Логістика та управління ланцюгом поставок. Львів : Видавництво Львівської політехніки, 2017. 804 с.

7. Кристофер М. Логистика и управление цепочками поставок. СПб : Питер, 2004. 316 с.

8. Литвинов А. Л. Теорія систем масового обслуговування : навч. посібник. Харків : ХНУМГ ім. О.М. Бекетова, 2018. 141 с.

9. Лісун Я.В. Формування логістичного забезпечення бізнес-проектів підприємств сфери послуг. Логістика: теорія та практика. Луцьк : ЛНТУ, 2012. № 1(2). С. 101-109.

10.Матеріали сайту Goldratt's Marketing Group. URL: http://www.toc-goldratt.com/ (дата звернення: 23.11.2020).

11.Мередит Дж., Мантел С. Управление проектами : 8-е изд. СПб : Питер, 2014. 640 с.

12. Ноздріна Л.В., Ящук В.І., Полотай О.І. Управління проектами : підручник / за заг. ред. Л.В. Ноздріної. Київ, 2010. 432 с.

13. Окландер М.А. Логістична система підприємства : монографрія. Одеса : Астропринт, 2004. 312 с.

14. Петрович Й.М., Новаківський І.І. Управління інноваційними проектами : навч. посібник / за заг. ред. Й.М. Петровича. Львів : Видавництво Львівської політехніки, 2016. 316 с.

15. Рыжиков Ю.И. Теория очередей и управление запасами. СПб : Питер, 2002. 259 с.

16. Стройко Т.В. Логістична інфрраструктура як ефективний інструмент управління підприємством. Ефрективна економіка. № 9. 2011. URL: http://www.economy.nayka.com.ua/?op=1\&z=684

17. Тарасенко Л.М. Управління проектами : навч. посібник. Київ, 2006. 280 с.

18.Управління проектами в логістиці. URL: https://58866/logistika/upravlinnya_proektami_logistike (дата звернення: 7.12.2020).

19. Цимбалістова О.А. Логістичне забезпечення інноваційної активності авіакомпанії : дис. ... канд. екон. наук : 08.00.04. Київ, 2018. 305 с.

20. Чухрай Н., Матвій С. Перепроектування логістичних бізнес-процесів у ланцюгах поставок. Вісник Нац. ун-ту «Львівська політехніка» «Логістика». Львів, 2014. № 811. С. 315-323.

21. Bhaskar V., Lallement P. Modeling a supply chain using a network of queues. Applied Mathematical Modelling. 2012. Vol. 34. Issue 8. P. 2074-2088. doi: https://doi.org/10.1016/j.apm.2009.10.019

22. Camaj J., Dolinayova A., Lalinska J., Bariak M. The Technological Problem of Simulation of the Logistics Centre. 17th International Conference on Logistics and Transportation (Dubai, UAE, 8-9 April, 2015). Dubai : World Academy of Science, Engineering and Technology, 2015. P. 2613-2617.

23. Camaj J., Lalinska J., Masek J. Simulations of continental logistics centre from the perspective of technologist. International Conference on Industrial Engineering, Management Science and Applications: Proceeding book of conference. Beijing : IEEE, 2014. P. 305-308.

24. Ciesielski M. Logistyka we współczesnym zarządzaniu. AE Poznań, 2004. 138 p.

25. Hillier F., Lieberman G. Introduction to Operation Research, 9th ed. NY : McGraw Hill, 2012.

26. Kerzner H. Project Management: A Systems Approach to Planning, Scheduling and Controlling, $10^{\text {th }}$ ed. New Jersey : Wiley, 2009. 891 p.

27. Kowalska K. Logistyka zaopatrzenia: podręcznik. Katowice : AE w Katowicach, 2005.

28. Masek J., Camaj J., Nedeliakova E. Application the Queuing Theory in the Warehouse Optimization. International Journal of Industrial and Manufacturing Engineering. World Academy of Science, Engineering and Technology, 9(11). 2015. P. 3744-3748. doi: https://doi.org/10.5281/zenodo.1109511

29. Sadowski W. Teoria podejmowania decyzji. Warszawa : PWE, 1969.

30. Wasiak M. Odwzorowanie systemów logistycznych jako systemów masowej obsługi. Systemy logistyczne. Teoria i praktyka: Materiały konferencyjne - Międzynarodowa Konferencja Naukowo-Techniczna. Warszawa, 2006.

\section{REFERENCES:}

1. Bauersoks, D. \& Kloss, D. (2006). Lohystyka: intehrirovannaia tsep' postavok [Logistics: the integrated supply chain], $2^{\text {d }}$ ed. Moscow: Olimp-Biznes. (in Russian)

2. Hryhorak, M.Yu. (2016). Analiz biznes-modelei ta stratehii innovatsiinoho rozvytku postachalnykiv lohistychnykh posluh [Analysis of business models and strategies for innovative development of logistics service providers]. Tekhnologicheskiy audit i rezervy proizvodstva, 2(5), 29-38. DOI: 10.15587/2312-8372.2016.65948 (in Ukrainian) 
3. Goldratt, E. M., \& Koks, D. (2004). Tsel. Protsess nepreryivnogo sovershenstvovaniya [The Goal: A Process of Ongoing Improvement]. Minsk: Popurri. (in Russian)

4. Detmer, U. (2010). Teoriya ogranicheniy Goldratta. Sistemnyiy podhod k nepreryrvnomu sovershenstvovaniyu [Goldratt's theory of constraints. A systematic approach to Ongoing Improvement]. Moskva: Alpina Pablisher. (in Russian)

5. Domina, V.M. (2015). Optymizatsiini metody ta modeli. Modeliuvannia system masovoho obsluhovuvannia: konspekt lektsii [Optimization methods and models. Modeling queuing systems: lecture notes]. Kharkiv: KhNAU. (in Ukrainian)

6. Krykavs'ky], Ye., Pokhyl'chenko, O., \& Fertch, M. (2017). Lohistyka ta upravlinnia lantsiuhom postavok [Logistics and supply chain management]. Lviv: Vydavnytstvo L'vivs'koi politekhniky. (in Ukrainian)

7. Kristofer, M. (2017). Logistika i upravleniye tsepochkami postavok [Logistics and supply chain management]. SPb: Piter. (in Russian)

8. Lytvynov, A.L. (2018). Teoriia system masovoho obsluhovuvannia: navch. posibnyk [Queuing systems theory: a tutorial]. Kharkiv: KhNUMH im. O.M. Beketova. (in Ukrainian)

9. Lisun, Ya.V. (2012). Formuvannia lohistychnoho zabezpechennia biznes-proektiv pidpryiemstv sfery posluh [Formation of logistics support for business projects of service enterprises]. Lohistyka: teoriia ta praktyka, 1(2), 101-109. (in Ukrainian)

10. Materialy saitu Goldratt's Marketing Group [Materials of the site Goldratt's Marketing Group]. Retrieved from: http://www.toc-goldratt.com/

11. Meredith, J., \& Mantel, S. (2014). Upravleniye proyektami [Project Management]. (8 $8^{\text {th }}$ ed.). SPb: Piter. (in Russian)

12. Nozdrina, L.V., Yashchuk, V.I., \& Polotai, O.I. (2010). Upravlinnia proektamy: pidruchnyk [Project Management: A Tutorial] / za zah. red. L.V. Nozdrinoi. Kyiv. (in Ukrainian)

13. Oklander, M.A. (2004). Lohistychna systema pidpryiemstva: monohrafiia [Logistics system of the enterprise: monograph]. Odesa: Astroprynt. (in Ukrainian)

14. Petrovych, Y.M., \& Novakivskyi, I.I. (2016). Upravlinnia innovatsiinymy proektamy: navch. posibnyk [Management of innovative projects: a tutorial] / za zah. red. Y.M. Petrovycha. Lviv: Vydavnytstvo Lvivskoi politekhniky. (in Ukrainian)

15. Ryizhikov, Yu.I. (2002). Teoriya ocheredey i upravlenie zapasami [Queuing theory and inventory management]. SPb: Piter. (in Russian)

16. Stroiko, T.V. (2011). Lohistychna infrastruktura yak efektyvnyi instrument upravlinnia pidpryiemstvom [Logistics infrastructure as an effective enterprise management tool]. Efektyvna ekonomika, 9. Retrieved from: http://www.economy.nayka.com.ua/?op=1\&z=684 (in Ukrainian)

17. Tarasenko, L.M. (2006). Upravlinnia proektamy: navch. posibnyk [Project Management: A Tutorial]. Kyiv. (in Ukrainian)

18. Upravlinnia proektamy v lohistytsi [Project management in logistics]. Retrieved from: https://58866/logistika/ upravlinnya_proektami_logistike

19. Tsymbalistova, O.A. (2018). Lohistychne zabezpechennya innovatsiynoyi aktyvnosti aviakompaniyi [Logistic support of the airline's innovative activity]. Candidate's thesis. Kyiv. (in Ukrainian)

20. Chukhrai, N., \& Matvii, S. (2014). Pereproektuvannia lohistychnykh biznes-protsesiv u lantsiuhakh postavok. Visnyk Nats. un-tu «Lvivska politekhnika» «Lohistyka», 811, 315-323. (in Ukrainian)

21. Bhaskar, V., \& Lallement, P. (2012). Modeling a supply chain using a network of queues. Applied Mathematical Modelling. 34(8), 2074-2088. doi: https://doi.org/10.1016/j.apm.2009.10.019

22. Camaj, J., Dolinayova, A., Lalinska, J., \& Bariak, M. (2015). The Technological Problem of Simulation of the Logistics Centre. Proceedings from ICLT '15: 17th International Conference on Logistics and Transportation (Dubai, UAE, 8-9 April, 2015), pp. 2613-2617. Dubai: World Academy of Science, Engineering and Technology.

23. Camaj, J., Lalinska, J., \& Masek, J. (2014). Simulations of continental logistics centre from the perspective of technologist. Proceedings from ICIMSA '14: International Conference on Industrial Engineering, Management Science and Applications, pp. 305-308. Beijing: IEEE.

24. Ciesielski, M. (2004). Logistyka we współczesnym zarządzaniu [Logistics in modern management]. Poznań: AE. 25. Hillier, F., \& Lieberman, G. (2012). Introduction to Operation Research, $9^{\text {th }}$ ed. NY: McGraw Hill.

26. Kerzner, H. (2009). Project Management: A System Approach to Planning, Scheduling and Controlling. $\left(10^{\text {th }}\right.$ ed.). New Jersey: John Wiley \& Sons.

27. Kowalska, K. (2005). Logistyka zaopatrzenia: podręcznik [Supply logistics: manual]. Katowice: AE w Katowicach.

28. Masek, J., Camaj, J., \& Nedeliakova, E. (2015). Application the Queuing Theory in the Warehouse Optimization. International Journal of Industrial and Manufacturing Engineering, 9(11), 3744-3748. doi: https://doi.org/ 10.5281/zenodo.1109511

29. Sadowski, W. (1969). Teoria podejmowania decyzji [Decision making theory]. Warszawa: PWE.

30. Wasiak, M. (2006). Odwzorowanie systemów logistycznych jako systemów masowej obsługi [Display of logistics systems as queuing systems], Materiały konferencyjne: Międzynarodowa Konferencja Naukowo-Techniczna «Systemy logistyczne. Teoria i praktyka» - The International Scientific and Practical Conference «Logistic systems. Theory and practice». Warszawa. 